\title{
22 Four genealogies of postsecularity
}

\author{
Kristina Stoeck1 and Dmitry Uzlaner
}

\section{Introduction}

For the Russian formalist literary critic Victor Shklovsky (1893-1984), the purpose of art was to turn the familiar object into something unfamiliar and strange, thus enabling the spectator to behold the object anew. A piece of art, a theatre performance, or a cinematographic scene has the power 'to make the stone stony', he wrote, meaning that they break up habitual perceptions and open the gaze to the essence of an object (Shklovsky 1991 [1925]). The liberating effect of distancing and estrangement is valid not only in the sphere of art, but also applies to social theories. Social theories develop in specific contexts, frequently with the purpose to give sense and order to a confusing reality in a particular time and space. It is once we take them out of their original context that theories and concepts reveal their potential to flourish or, on the contrary, their limitations and contradictions.

Postsecularity is one such concept that is put to the test when taken outside of the Western context where it originally emerged. In our contribution to the Handbook, we look at postsecularity through the lens of its perception in the Russian scholarly context. This exercise in distancing oneself from the original — Western academic — context of the theory has the purpose to free the imagination for a critical analysis. The Russian lens, we will argue, allows us to discern four different genealogies that inform postsecularity: the sociological, the normative, the postmodern, and the theological. All of these genealogies have to a certain extent produced their own postsecularity, but due to the high specialization of Western academia, they don't usually intersect and therefore rarely clash. In the Russian context, on the contrary, all four genealogies 
are received and interpreted simultaneously. The Russian lens therefore reveals the differences and commonalities between existing approaches to postsecularity. ${ }^{1}$

\section{Postsecularity: a variety of approaches to a complex phenomenon}

Since the late 1990s, debates on postsecularity have multiplied, developing the concept into different disciplinary directions: sociology, normative political theory, philosophy, and theology. In front of such proliferation, the sociologist James Beckford came to the conclusion that the notion of postsecularity was problematic in itself and that it offered no help in explaining important recent trends connected to religion and secularity (Beckford 2012: 16-17). Beckford claimed, in particular, that 'it is not easy to reconcile the idea that the secular has somehow come to an end with the idea that postsecularity represents a refinement - or a more productive phase — of secularity' (2012: 12). Beckford is right in his observation that the concept of postsecularity has proliferated into different directions that are not easily reconcilable with each other, but he underestimates the underlying unity of the existing approaches.

Several authors have offered their own meta-analyses of postsecularity, pointing to multidimensional interpretations while attesting to the underlying unity of existing approaches (McLennan 2007, 2010a, 2010b; Uzlaner 2011, 2013; Cistelecan 2014; Molendijk 2015; Parmaksız 2016; Fordahl 2017; Bradotti 2008). Arie Molendijk, for example, comes to the conclusion that "the emergence of the "postsecular" refers to very real phenomena, the most important being the "intertwinement" of the secular and the religious in sometimes new forms' (2016: 110). George McLennan stresses the importance of understanding postsecularity as 'intrasecular rather than anti-secular' (2010a: 19), as critical exploration of faults and limits of secularity rather than straight rejection of it. Clayton Fordahl emphasizes hyper-reflexivity and anxiety over taken-for-granted conceptions regarding religion and secularity (2017: 564-65), 
while Bradotti analyses the impact of postsecular theory on feminism (Bradotti 2008). Umut Parmaksiz, finally, praises postsecularity for challenging 'the natural status ascribed to the secular, interrogating seculanormativity in the social, political and cultural realms' (2016: 111). This attitude is echoed by Morteza Hashemi, who also sees in different manifestations of postsecularity 'a form of challenging the conception of the secular as the neutral' (2016:474), that is, as the neutral foundation which is beyond doubts and which is the shared background for all further processes and transformations. Our contribution adds to this line of argumentation. We take the existence of different interpretations of postsecularity not as a weakness in the theory, but rather as an indicator that the complex underlying experience of revision of the secularization thesis requires an equally complex response.

In the Western context, different academic disciplines-sociology, normative political theory, philosophy, and theology—cultivate different understandings of postsecularity. In the wellordered world of Western academia, these understandings do not usually intersect. In the Russian context, the situation is different. Genealogies of theoretical argument as distinct as the political liberalism of John Rawls and Jürgen Habermas are brought into interplay with the postmodernism of Slavoj Žižek or the radical orthodoxy of John Milbank. In the Russian perception, postsecularity from the beginning referred to a general paradigm shift—affecting different disciplines and working in different social, political, legal, and cultural contexts. What mattered was not concrete positions and nuances but the general understanding that 'religion is back' and that it is starting to refashion the theoretical and empirical landscape formed by previous decades and even centuries of secularization. It is this holistic Russian approach to the concept of postsecularity that provokes the distancing or estrangement effect that was hailed by 
Shklovsky as the essence of art, and which allows also the social theorist to cast a fresh look on the theoretical debates that define postsecularity.

\section{The sociological genealogy}

The first scholarly article to systematically introduce the term postsecular into Russian was 'A Postsecular Age: Religion and Culture Today' by Alexander Kyrlezhev (2004, published in English in 2008). It took another couple of years before the term gained wider prominence and a more systematic reception set in, mostly with the works of Dmitry Uzlaner (2008, 2011, 2013), Kyrlezhev (2011, published in English in 2012, 2013, 2014), and few others (cf. Morozov 2008; Shishkov 2010a; Horujy 2012). The authors who actively introduced the term into the Russian academic debate were sociologists of religion, philosophers, and theologians. The concept of postsecularity had an immediate sociological appeal in the Russian situation, characterized for over a decade already by religious revival and a renewed public role of the Russian Orthodox Church. Kyrlezhev defined secularization as "the age of war against religion and of the attempts to find substitutes for it' (Kyrlezhev 2008: 25). He identified the post-Soviet religious revival with postsecularity.

In the West, also, the sociological genealogy of postsecularity was connected with empirical claims regarding the demise of the secularization thesis and the widely shared agreement that modern societies are experiencing a 'return of religion' ${ }^{2}$ Postsecularity, in this context, had a great rival, the concept of desecularization introduced into the debate by Peter Berger (1999). However, postsecularity and desecularization tried to catch different dynamics in the situation of religious resurgence, with postsecularity stressing the transformative nature of the interaction of religion and secular modernity; and desecularization focusing more conventionally on religious restoration and religious-secular conflicts. In the Russian context, the difference between the two 
theoretical approaches was evident, with postsecularity-studies trying to detect changing modes of interaction between religion and Russian society on the level of practices and discourses (Uzlaner 2014), and desecularization studies focusing on the renewed role of Orthodoxy as a public religion and on church-state relations (Karpov 2010; Shishkov 2010b).

The aim of sociological studies of postsecularity has, on the whole, been the desire to show the transformative nature of religion in secular societies and to highlight the novelty of the postsecular religious constellation, rather than simply to argue a 'return of religion' (Rosati and Stoeckl 2012). Rosati, in his study on religion in post-Kemalist Turkey, highlighted novel aspects of religious practices in contemporary Turkey, for example the creation of nontraditional sanctuaries of prayer and commemoration (Rosati 2015). Geographers, theologians, and urban sociologists, such as Molendijk, Beaumont, and Jedan (2010), Beaumont and Baker (2011), Herman et al. (2012), and Baker et al. (2018), have, likewise, stressed the transformative role of religion in, what has been called, 'postsecular spaces of engagement', which differ from the spaces traditionally occupied by religious organizations.

All of these studies share the intuition that postsecular society is a place where the negotiation of the relation between different religions and between religions and secular worldviews is not a confrontation between self-contained ideological universes, but an encounter that unsettles each of the actors involved through a process of self-reflexivity. Against the grain of the concept of desecularization, these studies argue that what is happening in a situation of religious resurgence is not the return to a presecular, premodern religious status quo ante, but a novel constellation of pluralism. Such pluralism applies also to religions themselves, which are no longer studied as monoliths, but as multivocal bodies, as a part of highly pluralized societies, with which they interact in multiple ways. 


\section{The normative genealogy}

The normative genealogy of postsecularity is connected with the academic discipline of political theory and with political liberalism. The postsecular political liberal agenda has been shaped in particular by Rawls (1993) and by Habermas (2006) responding to Rawls. It has a clear normative dimension and has inspired a debate in political philosophy about 'reflexive' forms of secularism (cf. Ferrara, Kaul, and Rasmussen 2010; Calhoun, Juergensmeyer, and VanAntwerpen 2011; Gorski et al. 2012). Postsecular political liberalism holds that an ideology of secularism is not an integral part of liberalism and that secularism as a political ideology discriminates against religious citizens. All citizens must in principle be free to enter into public debates from within the framework of their 'comprehensive doctrines', provided that they are ready to deliberate over political norms in a reasonable fashion and in the view of a consensus that can become valid for all (the 'overlapping consensus').

Habermas' contribution to this debate is informed by his previous work on communicative action and deliberative democracy. The norms that underlie our modes of political coexistence, and this is Habermas' most basic position, do not lie out there in 'principles from nowhere' nor do we need to abandon the idea of general guiding norms in the light of a multiplicity of moralities and beliefs; agreement on 'principles valid for all' can, instead, emerge in the process of communication and deliberation, which can be the fruit of a mutual learning process and general consent. Habermas himself describes this kind of reasoning as 'post-metaphysical', because it affirms the validity of moral and political principles not by indication of some transcendental point of reference, but through an immanent deliberation process. The equality of public deliberation is threatened, however, when the secular public discourse renders it difficult for religious citizens to voice their arguments. Habermas responds to this particular problem with the 
assertion that not only should religious citizens be asked to translate their claims into the language of secular public discourse, but also the non-religious citizens are asked to play their part, namely, to scale down their secularist aspirations. Such a reciprocal work of translation should give rise to what he calls 'the complementary learning process' (2006). Habermas' concepts of translation and of the complementary learning process are premised on the idea that religions undergo a process of modernization in response to the challenges of religious pluralism, modern science, positive law, and profane morality. This notion of 'modernization of religious consciousness' has been accused of a secularist and ethnocentric bias by some commentators (Leezenberg 2010; Habermas 2011; Maclure and Taylor 2011).

In the Russian reception of postsecularity, the Habermasian normative understanding of postsecularity is strikingly absent. It is in particular the idea that religions in postsecular societies undergo a modernization process that is rejected. Kyrlezhev argued instead: 'Religion in the postsecular age does not need to adjust; there is no need for it to make itself "modern", because the western world has already moved on to the "postmodern" phase' (2008: 31). Even though Habermas was duly introduced to the Russian debate later on (Uzlaner 2011), the Habermasian version of postsecularity has remained of secondary importance. One reason for this neglect could be that the Habermasian genealogy implicitly presupposes a set of conditions, namely, the institutional context of liberal democracy and the existence of an academic theology or academic philosophy of religion (Stoeckl 2014b), that are largely absent in the Russian context. Through the Russian prism, the limitations of the Habermasian normative genealogy of postsecularity stand out clearly. The persuasiveness of this political liberal genealogy, which has arguably been the motor of the debate on postsecularity in the West, has no parallel in Russia. The Russian 
readers were not really interested in the normative genealogy of postsecularity from the start and identified their authoritative source for postsecularity elsewhere: in the postmodern genealogy.

\section{The postmodern genealogy}

The Russian reception linked postsecularity to postmodernity. 'The start of the postsecular age coincides with the start of the postmodern age', Kyrlezhev wrote, because 'postmodernism gives freedom to religion as religiosity'. 'Postmodern indifference' was the ground on which 'postsecular attitudes [could] grow' (2008: 25). The Western key authors in the Russian reception of postsecular social theory were theologians like John Milbank (his 'Beyond secular reason: theology and social theory', 1993) and_-for some of them-John Caputo (his chapter 'How the secular world became post-secular' in 'On religion', 2001: 37-66), or philosophers and

critical theorists such as Charles Taylor, Slavoj Žižek, and Talal Asad (see Uzlaner 2011 for the first Russian collected volume on postsecularity).

The postmodern genealogy of postsecularity — though some of the mentioned authors might object to the label 'postmodern' - is connected with the linguistic turn in philosophy, the constructivist turn in the social sciences, and with critical theory. Based on Lyotard's definition of the postmodern condition (Lyotard 1984), the key component of postmodern secularity is reflexivity. Heeding the lesson of the linguistic turn, the modern secular self-understanding of the social and political sciences appears as one 'grand narrative' and secularism as a form of authority (Connolly 1999). Postmodern philosophers discover religion as a reservoir of meaning, on which they draw independently of specific religious traditions of interpretation (Derrida and Vattimo 1998; Žižek 2000; Nancy 2008); critical theorists in all disciplines scrutinize the inbuilt biases in the theories and concepts they are working with. The postmodern perspective perceives 
postsecularity as a constitutive element of a postmodern turn which marks a rethinking of key tenets of modernity and rejection of religion as the most important of these tenets (Caputo 2001: 37). This leads to 'contamination of philosophy with theological thinking' or to the 'theologisation of philosophy' (Smith and Whistler 2010: 2). This postmodern dimension of postsecularity is closely connected to genealogical studies about the modern construction of the religion-secular binary, which shows how both modern religion and modern secularity as two incompatible dimensions are not some eternal entities, but artificial constructs resulting from theoretical and political efforts dating back at least to the fifteenth century (Despland and Vallee 1992; Asad 1993, 2003; Molnar 2002; Dubuisson 2003; Masuzawa 2005; Fitzgerald 2007; Hurd 2008; Cavanaugh 2009; Nongbri 2013; Sullivan et al. 2015).

Postsecularity becomes, in this genealogy of argumentation, the study of religion and society after the rejection of strong assumptions of the secularization thesis and after the deconstruction of conceptualizations of religion in the Western social sciences. In this sense, the postmodern genealogy of postsecularity is also a genealogy of postreligion, if by religion we understand the modern concept of 'religion' which is being deconstructed.

It is important to note, however, that not all theoretical literature and empirical studies associated with the postmodern genealogy of postsecularity use the term 'postsecular'. Some even reject the label. For example, Slavoj Žižek criticizes the term as closely connected to 'a new reenchantment of the world' (Žižek and Milbank 2009: 255-6). It is in the Russian reception that the postsecular nature of Žižek's thinking is highlighted. Žižek, Giorgio Agamben, and Alain Badiou with their turn to St Paul and political theology are read as founders of an alternative postsecular philosophy, alternative both to the political liberal postsecularity of Habermas and to 'the 
postsecular version of deconstructionism' (Žižek and Milbank 2009: 256) as represented by Jacques Derrida or John Caputo (Uzlaner 2011: 10).

McLennan has described the range of postsecular approaches that we are presenting as four separate genealogies as a continuous spectrum, ranging from 'religious' approaches such as Radical Orthodoxy (RO) to secular-materialist positions such as held by Žižek. In McLennan's scheme, Habermas and Derrida sit in a 'middle range' (McLennan 2010a: 4). McLennan's arrangement comprises, in our systematic approach, the normative, philosophical, and theological genealogy. The three meta-theoretical outlooks that he identifies-genealogical, neovitalist, and postcolonial anti-historicist—do not overlap with our threefold disciplinary distinction but add an additional layer that identifies strategies vis-à-vis secularism across the board of different approaches.

\section{The theological genealogy}

The Russian reception of postsecular social theory highlights a fourth genealogy of postsecularity, which exists somewhat in isolation from the sociological study of the phenomenon: theology. This fourth genealogy is logically connected to the reflexive turn in philosophy, for which both the normative and the postmodern genealogy are representative. It constitutes its reverse side: secular philosophy reflects upon its secularist bias and opens itself towards religion as a result (what has been called 'theological turn', see Janicaud 1991); theology also reacts to this postmodern turn perceiving it as a chance to re-enter into postsecular philosophy and social theory on its own grounds (Blond 1997). As James K. Smith in his reflections on postsecular theology makes clear: 
the theoretical foundations for the secular have been systematically dismantled. So if we are witnessing the advent of the postmodern ..., then we should also be seeing the advent of the post-secular. And insofar as twentieth-century Christian theology ... allied itself with the Enlightenment project, resigning itself to an 'apologetic' project of correlation with secular thought, the demise of modernity must also spell the demise of such theology.

(Smith 2004: 33)

The postmodern postsecular turn is perceived as a kind of emancipation for Christian theology, which is now free to develop without constant looking back at secular philosophy and ontology (see Smith 2006). Postmodern philosophers, in turn, look to theology as 'a key "site of resistance" against the alienations of what is perceived as a singularly Western modernity' (Žižek and Milbank 2009: 255-6). This leads to the blurring of the boundary between theology and philosophy and to the expansion of theological-philosophical discussion, where secular philosophers engage in theological reflections and theologians reinterpret key philosophical concepts along theological lines.

It is important to stress that there is a bifurcation in the theological treatment of postsecularity depending on whether the authors stand in the postmodern or the normative lineage of postsecularity. We can, in fact, speak of two theological genealogies of postsecularity: one theological postmodern, the other theological normative. For both, modern philosophy has become self-reflexive to the point that it overcomes its secular bias and opens itself towards religion and theology.

The theological postmodern genealogy moves in the direction of a rather radical rethinking of the distinctions between religion and secularity, faith and reason, philosophy and theology, and so on; this is a search 'for another modernity' or for alternative versions of modernity beyond the 
secular and liberal model. Theological postmodern postsecularity is far from unanimous - this is a pluralistic, burgeoning conflict field ranging from Milbank's 'Radical Orthodoxy' (Milbank 1993), to Caputo's spiritual deconstruction (Caputo 2001; Caputo and Vattimo 2009), to Michel Henry and Jean-Luc Marion's theological turn in phenomenology (Staudigl and Alvis 2016), to Žižek's 'theology of the death of God' (Žižek and Milbank 2009: 110-233).

The theological normative genealogy, on the other hand, remains in the mainstream of Western philosophy: it limits itself to accurate dialogue and complementary learning without attempts to renew foundational distinctions of modernity. This theological normative genealogy has also produced interdisciplinary debates between philosophers and theologians, whose aim, however, has not been to go beyond foundational aspects of modernity, but rather to reconnect secular modernity with its religious component. Habermas' famous dialogue with Cardinal Ratzinger (Pope Benedict) (Habermas and Ratzinger 2006), and publications of Christian theologians discussing Habermas' ideas (cf. Habermas et al. 2010; Mrówczynski-Van Allen et al. 2016), put theology into the centre of postsecular processes of 'translation' between secular and religious arguments. To this field we may add sociologists of religion who study theological discourses from the angle of postsecular theory and examine how church doctrine and secular realities intersect (Stoeck1 2014a; Dillon 2018).

\section{Conclusion}

At the time when a handful of Western scholars were arguing over the question whether a postsecular social theory was meaningful at all, or tried to operationalize the theory for concrete empirical studies, or discussed the normative implications of it, their Russian colleagues took the term at face value. Applying postsecular social theory to the Russian situation promised new 
avenues for thinking about religion, state, and society beyond the dichotomy of Soviet atheism and Orthodox religious restoration. By working out this research agenda, the Russian reception of postsecular social theory made visible and tangible what Western debates on postsecularity tend to conceal, namely, the existence of four separate genealogies. However, through the Russian lens we also glance that we are dealing not with unconnected debates, as Beckford (2012) remarked critically, but with a more general paradigm shift that manifests itself differently across different contexts. This shift is essentially about the questioning of the modern secular paradigm, according to which secular reason and a secular public sphere were the stable, neutral, taken-for-granted ground on which all other processes evolve. From the postsecular perspective, this ground becomes now the site of intense debate and even conflict, a space of 'uncertainty concerning the religious-secular configuration' (Kyrlezhev 2004: 101). Our identification of four genealogies of postsecularity tries to advance an orderly exploration of this new space of uncertainty.

Every research on postsecularity connects to one of the aforementioned four genealogies; actually, most studies connect to more than one. The four genealogies that we have identified in this essay function as epistemological backdrop for the selective gaze of scholars; they determine the methodology, the processes, and the material that come under scrutiny. The Russian lens brings these four genealogies as well as their unity into focus. The Russian readers are less professionally biased in their reception of Western debates than Western academics, who tend to stay within the bounds of their disciplines. After the closed world of Soviet censorship, since the 1990s, the Russian humanities and social sciences have caught up with Western scholarship all at once. For that reason, they tried to grasp the picture in general while worrying much less about subtleties in debates, chronological phases, and incompatibilities of schools of thought. The 
Russian reception of postsecular social theory moved from the very beginning along the lines of a broad 'postsecular turn', embracing all four genealogies of postsecularity and interpreting them as a rethinking of secularism as a kind of a new openness to religion and theology.

This reception has produced a highly original debate on postsecularity, but one which has been difficult to 'translate back' into the Western context. This essay is actually an attempt to do precisely that. In the mindboggling situation of post-Soviet religious life in Russia, where theological reform exists side by side with religious fundamentalism, where the boundaries between the secular and the religious are in constant flux, and where fierce battles of ideas (and not only ideas) are being waged over Russian identity, culture, and politics, postsecular social theory has a considerable emancipatory and critical potential, because it starts from the assumption that pluralism, and not the dichotomous secular-religious divide, is the basic feature of society. But the term has also not been immune to abuse, and for several years already one can witness representatives of the Russian Orthodox Church make use of 'postsecular theory' in order to bestow scientific credentials to their claims for privilege in the secular Russian state. In this context, it is even more important that postsecularity as a research programme is upheld as a critical endeavour.

\section{Notes}

${ }^{1}$ The purpose of this essay is theoretical. The overview on the Russian reception of the postsecular, which is mostly of interest to an expert readership, is kept purposefully short. For an extensive overview and analysis of the Russian reception of Western theories of secularization, desecularization, and the postsecular, see Stoeckl and Uzlaner (2018). The authors acknowledge support by the grant ERC-STG-2015-676804 for the writing of this essay.

${ }^{2}$ Many sociologists of religion have rejected the idea that the situation of increased public visibility of religion, the heightened focus on religion in politics and society, and rising levels of religious pluralism warrants the necessity to add the postsecular qualifier (cf.Turner 2010; Gorski et al. 2012). Critics of the postsecularity concept argue that the (renewed) vitality of religion 
under modern conditions is a novelty only in a restricted European context and common reality in most other parts of the world (cf. Eder 2002; Burchardt, Wohlrab-Sahr, Middell 2015).

\section{Further reading}

Rosati, M. and K. Stoeckl (eds.) (2012) Multiple Modernities and Postsecular Societies, Farnham: Ashgate.

This edited volume offers an exemplary series of case-studies in the sociological genealogy of postsecularity, comprising cases from Turkey, Iran, Nepal, Russia, and Nigeria. The introduction and the first chapter on multiple democracies make clear how the normative perspective can intersect with sociological studies on postsecularity.

Calhoun, C., Mendieta, E and J. VanAntwerpen (eds.) (2013) Habermas and Religion, Cambridge: Polity.

This edited volume contains one of the most up-to-date and comprehensive discussion of Habermas' engagement with religion and with his ideas about postmetaphysical thought and postsecular consciousness. It is therefore the ideal starting point for the study of the normative genealogy of postsecularity.

Connolly, W. E. (1999) Why I am not a Secularist, Minneapolis: University of Minnesota Press. Connolly's book is a classic for postsecular social theory and a foundational text for the postmodern genealogy of postsecularity.

Smith, J. K. (2004) Introducing Radical Orthodoxy: mapping a post-secular theology, Grand Rapids, MI: Baker Academic.

This theological work, directed to a Christian readership, explains the foundations and trends of the theological genealogy of postsecularity in its postmodern key. The author is a representative of the RO first propagated by John Milbank.

\section{References}

Asad, T. (1993) Genealogies of Religion, Baltimore, MD: The Johns Hopkins University Press. 
- (2003) Formations of the Secular. Christianity, Islam, modernity, Stanford: Stanford University Press.

Baker, C., Cloke, P., Sutherland, C. and A. Williams (2018) Postsecular Geographies: reenvisioning politics, subjectivity and ethics, Abingdon: Routledge (in press).

Beaumont, J. and C. Baker (eds.) (2011) Postsecular Cities: space, theory and practice, London: Continuum.

Beckford, J. (2012) 'SSSR Presidential Address: public religions and the postsecular: critical reflections', Journal for the Scientific Study of Religion, 51(1): 1-19.

Berger, P. L. (1999) 'The desecularization of the world: a global overview'. In Berger, P. L. (ed.) The Desecularization of the World: resurgent religion and world politics, Washington, D.C.: Ethics and Public Policy Center, pp. 1-18.

Blond, P. (ed.) (1997) Post-Secular Philosophy: between philosophy and theology, London/New York, NY: Routledge.

Bradotti, R. (2008) 'In spite of the times: the postsecular turn in feminism', Theory, Culture \& Society, 25(1): 1-24.

Burchardt, M., Wohlrab-Sahr, M. and M. Middell (eds.) (2015) Multiple Secularities Beyond the West: religion and modernity in the global age, Boston, MA: de Gruyter.

Calhoun, C., Juergensmeyer, M. and J. VanAntwerpen (eds.) (2011) Rethinking Secularism, Oxford: Oxford University Press.

Caputo, J. D. (2001) On Religion, London/New York, NY: Routledge.

Caputo, J. D. and G. Vattimo (2009) After the Death of God, edited by J. W. Robbins, New York, NY: Columbia University Press.

Cavanaugh, W. T. (2009) The Myth of Religious Violence: secular ideology and the roots of modern conflict, Oxford: Oxford University Press.

Connolly, W. E. (1999) Why I am not a Secularist, Minneapolis, MN: University of Minnesota Press.

Cistelecan, A. (2014) 'The theological turn of contemporary critical theory', Telos, 167(Summer): 8-26.

Despland, M. and G. Vallee (eds.) (1992) Religion in History: the word, the idea, the reality ("La Religions dans L'histoire: le mot, l'idee, la realite"), Waterloo: Wilfred Laurier University Press. 
Derrida, J. and G. Vattimo (1998) Religion, Stanford: Stanford University Press.

Dillon, M. (2018) Postsecular Catholicism: relevance and renewal, Oxford: Oxford University Press.

Dubuisson, D. (2003) The Western Construction of religion: myths, knowledge and ideology, Baltimore, MD: The Johns Hopkins University Press.

Eder, K. (2002) 'Europäische säkularisierung: ein sonderweg in die postsäkulare sesellschaft?’ Berliner Journal für Soziologie, 12: 331-44.

Ferrara, A., Kaul, V. and D. Rasmussen (2010) 'Special issue: postsecularism and multicultural jurisdictions', Philosophy and Social Criticism, 36(3-4): 265-80.

Fitzgerald, T. (2007) Discourse on Civility and Barbarity: a critical history of religion and related categories, Oxford, NY: Oxford University Press.

Fordahl, C. (2017) 'The post-secular: paradigm shift or provocation? European Journal of Social Theory, 20(4): 550-68.

Gorski, P., Kyuman Kim, D., Torpey, J. and J. VanAntwerpen (eds.) (2012) The Post-Secular in Question: religion in contemporary societies, New York: New York University Press.

Habermas, J. (2006) 'Religion in the public sphere', European Journal of Philosophy, 14(1): 125.

- (2011) 'Dialogue. Jürgen Habermas and Charles Taylor', In Butler J. and J. VanAntwerpen (eds.) The Power of Religion in the Public Sphere, Columbia: Columbia University Press, pp. 60-69.

Habermas, J. and J. Ratzinger (2006) The Dialectics of Secularization: on reason and religion, San Francisco, CA: Ignatius Press.

Hashemi, M. (2016) ‘A post-secular reading of public sociology', Social Compass, 63(4): 46177.

Herman, A., Beaumont, J., Cloke, P. and A. Walliser (2012) 'Spaces of postsecular engagement in cities', In Beaumont, J. and P. Cloke (eds.) Faith-Based Organizatinons and Exclusion in European Cities, Bristol: Policy Press, pp. 59-80.

Horujy, S. S. (2012) 'Postsekulyarizm i antropologiya ("Postsecularism and anthropology")', Человек.rи, 8: 15-34.

Hurd, E. S. (2008) The Politics of Secularism in International Relations, Princeton: Princeton University Press. 
Janicaud, D. (1991) Le Tournant Théologique de la Phénoménologie Française, Combas: Éd. de l'Éclat.

Karpov, V. (2010) 'De-secularization: a conceptual framework', Journal of Church and State, 52(2): $232-70$.

Kyrlezhev, A. (2004) 'Postsekulyarnaya epokha (“The postsecular age”]', Kontinent, 120: 25264.

Kyrlezhev, A. (2008) 'The postsecular age: religion and culture today', Religion, State, and Society, 36(1): 21-31.

_(2011) 'Postsekulyarnoe: kratkaya interpretatsiya (“The postsecular: a brief interpretation”)' Logos, 3(28): 100-6.

_-(2012) 'Postsekulyarnaya kontseptualizatsiya religii: k postanovke problemy ("Postsecular conceptualization of religion: towards a formulation of the problem")', Gosudarstvo, Religiya, Tserkov’ v Rossii i za Rubezhom, 2(30): 53-68.

_(2013) 'Sekulyarizm i postsekulyarizm v Rossii i v mire ("Secularism and post-secularism in Russia and in the world”'), Otechestvennye Zapiski, 52(1): 175-92.

_(2014) 'A post-secular conceptualization of Rreligion: defining the question', State, Religion and Church, 1(1): 7-22.

Leezenberg, M. (2010) 'How ethnocentric is the concept of the postsecular?' In Molendijk, A. L., Beaumont, J. and C. Jedan (eds.) Op cit., pp. 91-112.

Lyotard, J.-F. (1984) The Postmoder Condition, Manchester: Manchester University Press.

Maclure, J. and C. Taylor (2011) Secularism and Freedom of Conscience, Cambridge, MA: Harvard University Press.

Masuzawa T. (2005) The Invention of World Religions, or, How European Universalism Was Preserved in the Language of Pluralism, Chicago: University of Chicago Press.

McLennan, G. (2007) 'Towards postsecular sociology?’ Sociology, 41(5): 857-70.

_(2010a) 'The postsecular turn', Theory, Culture \& Society, 27(4): 3-20.

- (2010b) 'Spaces of postsecularism'. In Molendijk, A. L., Beaumont, J. and C. Jedan (eds.) Op cit., pp. 41-62.

Milbank, J. (1993) Theology and Social Theory: beyond secular reason, Oxford: Blackwell. Molendijk, A. L. (2015) 'In pursuit of the postsecular', International Journal of Philosophy and Theology, 76(2): 100-15. 
Molendijk, A. L., Beaumont, J. and C. Jedan (eds.) (2010) Exploring the Postsecular: the religious, the political and the Urban, Leiden/Boston, MA: Brill.

Molnar A. (2002) 'The construction of the notion religion in early modern Europe', Method \& Theory in the Study of Religion, 14(1): 47-60.

Morozov, A. (2008) 'Has the postsecular age begun? Religion, State \& Society, 36(1): 39-44.

Mrówczynski-Van Allen, A., Obolevitch, T. and P. Rojek (eds.) (2016) Beyond Modernity: Russian religious philosophy and post-secularism, Eugene, OR: Pickwick.

Nancy, J.-L. (2008) Dis-enclosure: the deconstruction of Christianity, New York, NY: Fordham University Press.

Nongbri, B. (2013) Before Religion: a history of a modern concept, New Haven, CT/London: Yale University Press.

Parmaksız, U. (2016) 'Making sense of the postsecular', European Journal of Social Theory, 21(1): 98-116.

Rawls, J. (1993) Political Liberalism, New York, NY: Columbia University Press.

Habermas, J., Reder, M. and J. Schmidt (2010) An Awareness of What is Missing: faith and reason in a post-secular age, Hoboken, NJ: Wiley.

Rosati, M. (2012) The Making of a Postsecular Society: a Durkheimian approach to memory, pluralism and religion in Turkey, edited with a foreword by A. Ferrara. Farnham: Ashgate.

Rosati, M. and K. Stoeckl (eds.) (2012). Multiple Modernities and Postsecular Societies, Farnham: Ashgate.

Shishkov, A. (2010a) 'Osmyslenie poniatiya "postsekulyarnoe” v russkoyazychnoi periodike za poslednee desyatiletiye' ("Making sense of the "postsecular" in Russian language publications for the last ten years"), Bogoslov.ru, (28 April 2010), see www.bogoslov.ru/text/733826.html, accessed online 20-03-2018).

_ (2010b) 'Nekotorie aspekty desekulyarizatsii v postsovektskoj Rossii' ("Some aspects of desecularization in the post-Soviet Russia”), Gosudarstvo, Teligiya, Tserkov'v Rossii i za Rubezhom, 2(30): 165-77.

Shklovsky, V. (1991 [1925]) The Theory of Prose, Bloomington, IN: Dalkey Archive Press. Smith, J. K. (2004) Introducing Radical Orthodoxy: mapping a post-secular theology, with a foreword by John Milbank, Grand Rapids, MI.: Baker Academic. 
— (2006) Who's Afraid of Postmodernism? Taking Derrida, Lyotard, and Foucault to church, Grand Rapids, MI.: Baker Academic.

Smith, A. P. and D. Whistler (2010) After the Postsecular and the Postmodern: new essays in continental philosophy of religion, Cambridge: Cambridge Scholars Publishing.

Staudigl, M. and J. W. Alvis (2016) 'Phenomenology and the post-secular turn: reconsidering the "return of the religious", International Journal of Philosophical Studies, 24(5): 589-99.

Stoeckl, K. (2014a) The Russian Orthodox Church and Human Rights, London/New York, NY: Routledge.

- (2014b) 'The theology blind spot', Immanent Frame Blog of the Social Science Research Council (13 February 2014): http://blogs.ssrc.org/tif/2014/02/13/the-theology-blind-spot/, accessed online 20-03-2018.

Stoeckl, K. and D. Uzlaner (2018) 'The Russian postsecular'. In Schneider, C. (ed.) Theology and Philosophy in Eastern Orthodoxy, Eugene: Wipf and Stock, forthcoming.

Sullivan, W. F., Hurd, E. S., Mahmood, S. and P. G. Danchin (eds.) (2015) Politics of Religious Freedom, Princeton: Princeton University Press.

Susen, S. (2015) The 'Postmodern Turn' in the Social Sciences, London: Palgrave Macmillan.

Turner, B. S. (2010) 'Religion in a post-secular society'. In Turner, B. S. (ed.) The New Blackwell Companion to the Sociology of Religion, Oxford: Wiley-Blackwell.

Uzlaner, D. A. (2008) 'V kakom smysle sovremennyi mir mozhet byt' nazvan postsekulyarnym' ("In which sense can the contemporary world be called postsecular"), Kontinent, 136: 16.

- (2011) 'Vvedenie v postsekulyarnuyu filosofiyu' (“Introduction to postsecular philosophy”), Logos, 83(3): 2-32.

-(2013) 'Kartografiia postsekulyarnogo' ("Cartography of the postsecular”), Otechestvennye Zapiski, 1: 17.

- (2014) 'The pussy riot case and the peculiarities of Russian post-secularism', State, Religion and Church, 1(1): 23-58.

Žižek, S. (2000) The Fragile Absolute—or, why is the Christian legacy worth fighting for? London/New York: Verso.

Žižek, S. and J. Milbank (2009) The Monstrosity of Christ, edited by Creston Davis, Cambridge, MA: MIT Press. 